\title{
INCREASED PRODUCTION OF SAFRAMYCIN A AND ISOLATION OF SAFRAMYCIN S
}

\author{
Tadashi Arai, Katsuhiro Takahashi, Kimiko Ishiguro ${ }^{1)}$ \\ and KatsukiYo YaZawa ${ }^{2)}$ \\ Laboratory of Chemotherapy, Chiba Cancer Center Research Institute ${ }^{1)}$ \\ and Department of Antibiotics, Research Institute for \\ Chemobiodynamics, Chiba University, ${ }^{2)}$ Chiba City, Japan
}

(Received for publication May 19, 1980)

\begin{abstract}
This paper reports on an increased production of saframycin A, which is a satellite antibiotic to streptothricin and a trace component in the culture of Streptomyces lavendulae No. 314. Some improvement in the yield of the antibiotic was attained by supplementing the standard medium with two end-produtcs of metabolic pathways related to saframycin biosynthesis. A further significant increase of saframycin A potency could be attained by addition of $\mathrm{NaCN}$ to the culture broth. Finally, a drastic degradation of saframycin $\mathrm{A}$ in the culture was successfully prevented by maintaining the $\mathrm{pH}$ lower than 5.5 after peak production of the antibiotic. The combined application of these improvements resulted in approximately 1,000-fold increase in saframycin A production as compared with the parental level. The precursor of saframycin A in the culture, which yielded saframycin A upon cyanation was isolated, characterized and named saframycin S. Physicochemical properties of saframycin $\mathrm{S}$ were described and structural formulae were discussed.
\end{abstract}

Saframycins are satellite antibiotics which are co-produced in a trace quantity with streptothricin by Streptomyces lavendulae No. 314. The antibiotics are unique compounds which have a dimeric heterocyclic quinone skeleton in common. Among the saframycins, 5 components have been isolated and characterized to date and saframycin A has proved to be the most biologically active compound ${ }^{12}$. The structure of saframycin $\mathrm{C}$ was first elucidated by X-ray crystallography and subsequent studies revealed that saframycin $\mathrm{B}$ is $\mathrm{C}-14$ demethoxy saframycin $\mathrm{C}^{2)}$. On the other hand, saframycin $\mathrm{A}$ has nitrile group at $\mathrm{C}-21$ position of saframycin $\mathbf{B}^{3)}$. They are active against a number of Gram-positive bacteria and their antitumor activity on EHRLICH ascites tumor, mouse leukemias L1210 and P388, B16 melanoma and human tumor xonografts in nude mice has also been described ${ }^{4,5}$. Studies on the mode of action of saframycin A have also revealed a novel role of the nitrile group in its interaction with DNA ${ }^{6)}$.

The search for such satellite antibiotics among known species of streptomyces coupled with highly sensitive in vitro screening procedures, therefore, seems to hold out a fair chance of isolating unprecedented groups of antibiotics which are prone to be missed by the conventional screening procedures ${ }^{7}$. On the other hand, difficulty inheres in the development of such satellite antibiotics for chemotherapeutic agents because of their extremely low production in the culture of streptomyces. For example, the production of saframycins was as low as $0.01 \mathrm{mcg} / \mathrm{ml}$ of the culture filtrate in the initial stage of studies. The increased production of the antibiotics was attained to some extent by improving culture condition and medium ingredients. The way of circumventing the underlying obstacle, however, was found by the identification of the saframycin A precursor, saframycin S, and its subsequent cyanation to saframycin A. 
This paper describes the results of experiments for the increased production of saframycin A, the isolation and characterization of saframycin $\mathrm{S}$.

\section{Materials and Methods}

Strain

Streptomyces lavendulae No. 314 was used. The strain was maintained on glucose-asparagine agar slant.

\section{Fermentation}

Laboratory fermentations were run in 500 - $\mathrm{ml}$ shake flasks (SAKAGUCHI flask) at $27^{\circ} \mathrm{C}$ on a 125 stroke reciprocal shaker with an $8 \mathrm{~cm}$ throw. Each shake flask contained $80 \mathrm{ml}$ of the standard medium of the following composition (g/liter): glucose, 1; soluble starch, 10; Polypepton (Wako), 10; meat extract (Wako), 5; NaCl, 3; and Silicone KM-72F, $0.5 \mathrm{ml}$ (pH 7.0).

Jar fermentations were carried out by growing the organism at $27^{\circ} \mathrm{C}$ in aerated stainless steel 20 liter jar fermenters (Marubishi Co., Ltd. Type MSJ-U). An inoculum was prepared by growing the organism in shake flasks for 32 hours in the medium described above. One per cent inoculum was used to seed 12 liters of jar fermentation medium which contained the following ingredients $(\mathrm{g} / \mathrm{liter})$ : glucose, 5; soluble starch, 5; Polypepton, 10 ; meat extract, $5 ; \mathrm{NaCl}, 3$ (pH 7.0).

\section{Thin-layer chromatography (TLC) and TLC scanning}

TLC was carried out on silica gel plates Kiesel gel 60F 254 (E. Merck). The solvent system was ethyl acetate - benzene $(2: 1, \mathrm{v} / \mathrm{v})$ unless otherwise stated and TLC scanning was performed on a dual wavelength chromatogram scanner (Shimazu Seisakusho Co., Ltd., Model CS-910).

Biological assay and bioautography

The potency was determined by the paper disc method employing Bacillus subtilis $\mathrm{PCl} 219$ as a test organism for saframycins. The same organism was used for bioautography. Streptothricin concentrations in the culture broth were determined by the use of Escherichia coli $F_{1}$ which is not sensitive to saframycins.

\section{Results}

A thin-layer chromatogram of saframycins as revealed by ultraviolet absorption and DRAGENDORFF reaction is shown in Fig. 1. Saframycin A shows the most fast moving spot of $\mathrm{Rf} 0.5$, followed by saframycins D, C, B and E which gave $\mathrm{Rf}$ values of $0.25,0.2,0.15$ and 0.01 , respectively. The time course of saframycin production with reference to streptothricin production in the culture of $S$. lavendulae No. 314 in the standard medium in jar fermentation is shown in Fig. 2. The growth of the strain was extraordinarily rapid and the stationary phas e was attained within 24 hours. The production of streptothricin increased gradually and reached its maximum at approximately 30 hours of culture, while a steep rise in the production of
Fig. 1. TLC pattern of saframycins.

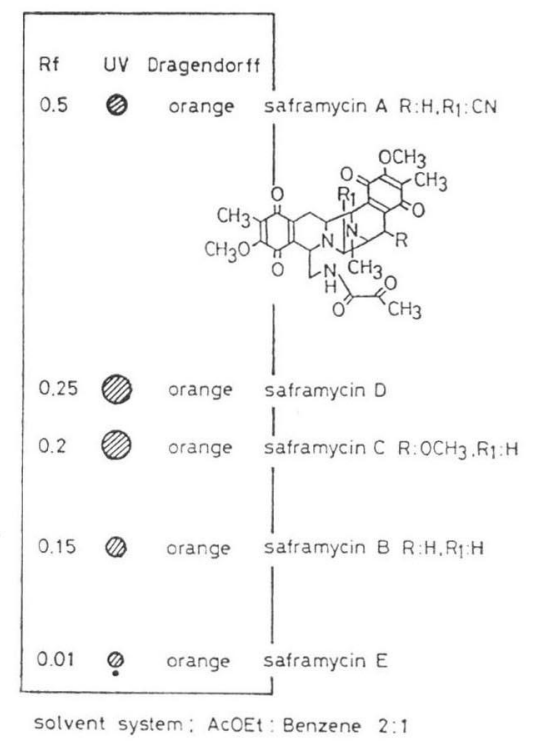


Fig. 2. Time course of saframycin fermentation.
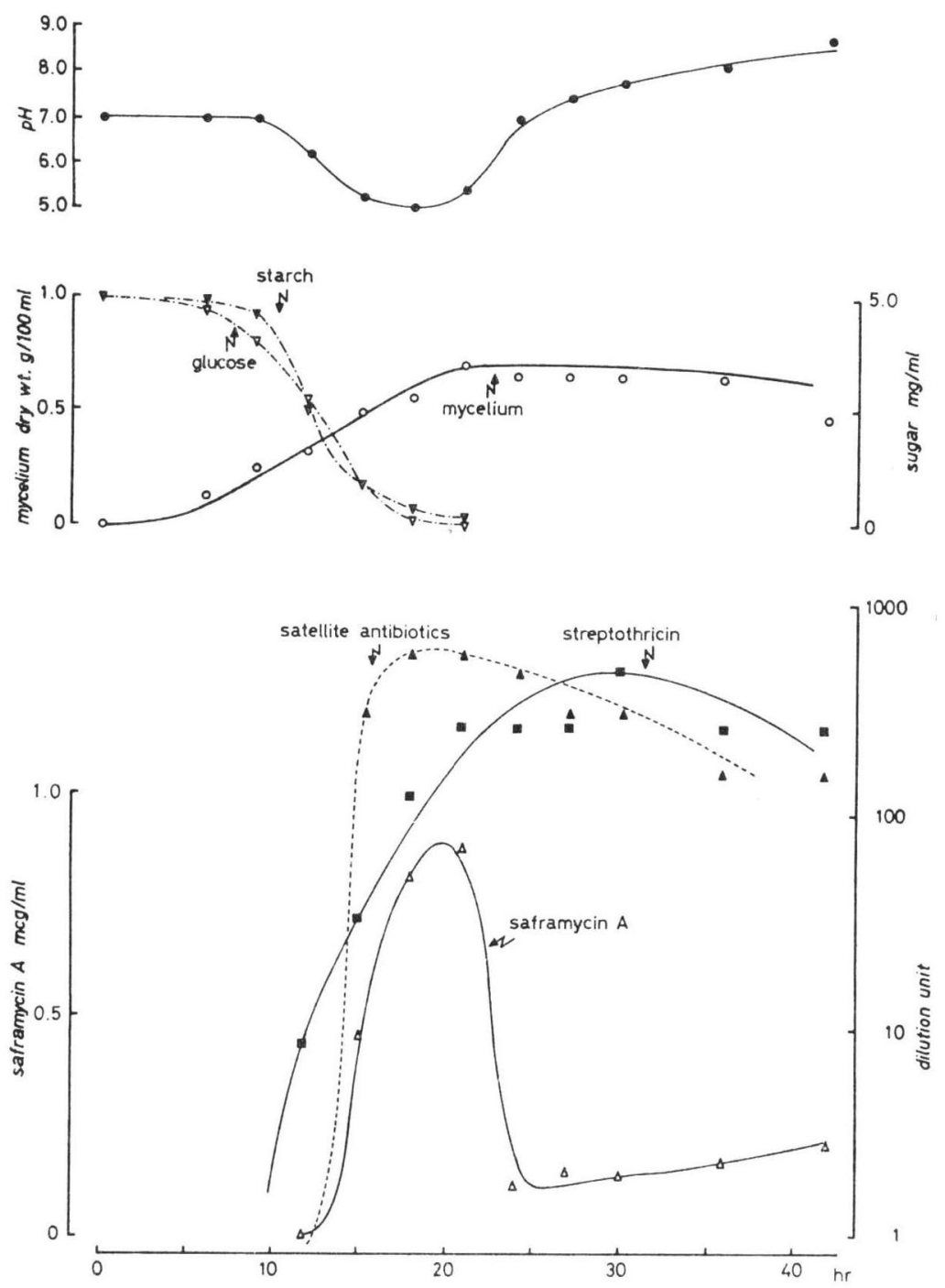

saframycins began just following the instant and characteristic violet coloration of the mycelia. Saframycin concentrations were determined after extracting the antibiotic from the broth samples with an equal volume of ethyl acetate at $\mathrm{pH}$ 7.5. The extract undoubtedly contained mimosamycin, ${ }^{8)}$ another satellite antibiotic, in addition to the saframycins. However, mimosamycin was almost inactive on Bacillus subtilis and its effect was negligible ${ }^{9)}$. The concentration of saframycin A, determined by thin-layer chromatography, also increased rapidly, followed by a sudden decrease within $1 \sim 2$ hours. Exhaustion of carbon sources resulted in cessation of growth and beginning of autolysis of the culture with a subsequent $\mathrm{pH}$ increase. It follows from the above experimental results that not only the advance in saframycin potency in the culture broth but also the inhibition of the rapid rate of degradation of the formed antibiotic is necessary for increased antibiotic production, especially in a large-scale production. 
Fig. 3. Effect of some metabolic intermediates on saframycin A production.
Fig. 4. Effect of aromatic amino acids on saframycin A production.
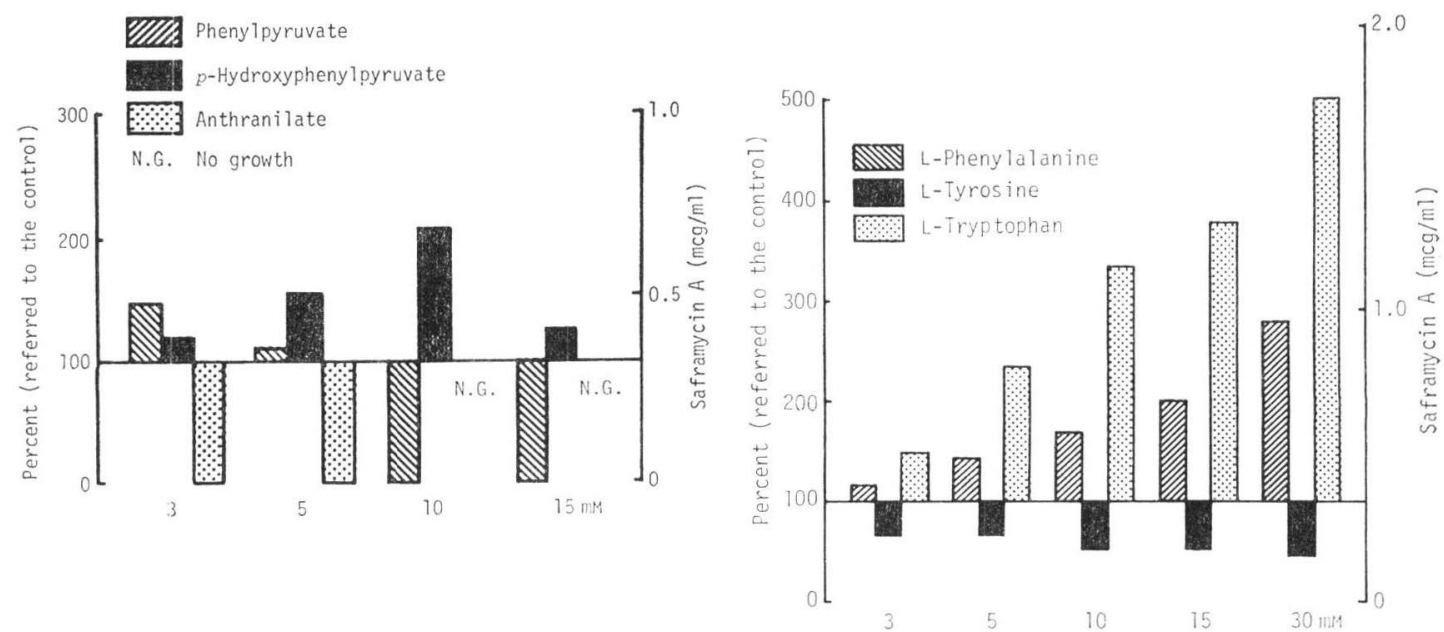

Effect of Medium Ingredients on Saframycin Production

Structural studies proved that all the saframycins contain a dimerized heterocyclic quinone moiety. Biosynthetic pathways leading to formation of the saframycin skeleton are thus postulated as via shikimate $\rightarrow$ chorismate $\rightarrow$ prephenate $\rightarrow$ tyrosine pathway. If this is actually the case, not only the intermediates in the pathway but also end-products of anthranilate or phenylpyruvate shunts might stimulate saframycin production by feedback regulation ${ }^{10)}$. The results of such experiments are shown in Figs. 3 and 4. p-Hydroxyphenylpyruvate supported a 2-fold increase of saframycin production, but no increase was observed with the addition of L-tyrosine, probably because of its low solubility. The incorporation of L-tyrosine into the saframycin skeleton, however, was evidenced by the labelling experiment of saframycin A by radioactive L-tyrosine. Phenylalanine and tryptophan, two end products of phenylpyruvate and anthranilate shunts stimulated the antibiotic production. The most stimulative effect was observed with L-tryptophan where the yield was increased about 5-fold of the original level.

Table 1. Potentiation of saframycin A concentration in culture filtrate by $\mathrm{NaCN}$.

\begin{tabular}{|c|c|c|c|}
\hline \multirow{3}{*}{$\begin{array}{l}\text { Age of the } \\
\text { culture } \\
\text { (hours) }\end{array}$} & \multicolumn{3}{|c|}{ Potency $(\mathrm{mcg} / \mathrm{ml})$} \\
\hline & \multirow{2}{*}{$\begin{array}{l}\text { Before } \\
\text { incubation }\end{array}$} & \multicolumn{2}{|c|}{$\begin{array}{c}\text { After 2-hour } \\
\text { incubation at } 27^{\circ} \mathrm{C}\end{array}$} \\
\hline & & $\begin{array}{l}\text { without } \\
\text { NaCN }\end{array}$ & $\begin{array}{l}\text { with } \\
\mathrm{NaCN}\end{array}$ \\
\hline 16 & 0.2 & 0.2 & 6.0 \\
\hline 24 & 0.043 & 0.098 & 3.9 \\
\hline 30 & 0.015 & 0.093 & 2.3 \\
\hline 40 & 0 & 0.012 & 0.87 \\
\hline 48 & 0 & 0.010 & 0.6 \\
\hline
\end{tabular}

Table 2. Cyanide formation by microorganisms.

\begin{tabular}{|c|c|c|c|}
\hline \multicolumn{3}{|c|}{ Organism } & $\begin{array}{c}\text { Cyanide } \\
(\mathrm{mcg} / \mathrm{ml})\end{array}$ \\
\hline \multicolumn{3}{|c|}{ Streptomyces lavendulae 314} & 0.138 \\
\hline "n & $"$ & IFM 1025 & 0 \\
\hline 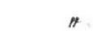 & $" \prime$ & IFM 1031 & 0.032 \\
\hline$"$ & $" \prime$ & IFM 1201 & 0 \\
\hline \multirow[t]{2}{*}{$"$} & racem & $\begin{array}{l}\text { tromogenes } \\
\text { IFM } 1029\end{array}$ & 0 \\
\hline & raceme & $\begin{array}{l}\text { zromogenes } \\
\text { IFM } 1191\end{array}$ & 0 \\
\hline " & aureof & iens IFM 1221 & 0 \\
\hline " & griseus & FM 1123 & 0 \\
\hline " & hygros & picus IFM 1136 & 0 \\
\hline$" \prime$ & netrop & IFM 1035 & 0 \\
\hline$"$ & venezu & ae IFM 1036 & 0 \\
\hline \multicolumn{3}{|c|}{ Chromobacterium violaceum } & 17 \\
\hline \multicolumn{3}{|c|}{ Pseudomonas aeruginosa } & 7.23 \\
\hline
\end{tabular}


Increase of Saframycin A Potency in Culture Filtrates

A considerable increase in saframycin potency was incidentally found by the addition of sodium cyanide to culture filtrates of Streptomyces lavendulae No. 314. The dependence of this effect on culture filtrates with respect to the age of the parent cultures is shown in Table 1. After 16-hours of culture growth, the saframycin A production had reached the peak of $0.2 \mathrm{mcg} / \mathrm{ml}$ and a 30 -fold potentiation of saframycin A activity of the culture filtrate was observed after 2-hour incubation with $1 \mathrm{~mm}$ $\mathrm{NaCN}$ at $27^{\circ} \mathrm{C}$. In spite of the significant drop in saframycin A potency which took place in cultures that had grown for 24 hours or even longer, the same relative potentiation occurred in their filtrates by incubation with $\mathrm{NaCN}$. Some increase in the concentration of saframycin A was noted by incubating the culture filtrate even without $\mathrm{NaCN}$. This increase might be ascribed to the delayed reaction of saframycin formation in situ.

The experimental results described above engendered considerable interest in the source of the nitrile group in the culture broth. Therefore, the cyanide formation of $S$. lavendulae as well as of some other Streptomyces species and bacteria was investigated. The results are summarized in Table 2. The production of cyanide by Chromobacterium violaceum and Pseudomonas aeruginosa was described by Michaels and CORPE ${ }^{11)}$ and by CASTRIC ${ }^{12)}$, respectively. Chromobacterium violaceum and Pseudomonas aeruginosa, propagated in nutrient broth, produced a considerable amount of cyanide, whereas only S. lavendulae No. 314 and IFM 1031 produced a small amount of cyanide. From these results it is evident that cyanide, present in the culture broth, plays an important role in the final step of saframycin A biosynthesis. In Fig. 5 is shown the qualitative analysis of saframycin in culture filtrate before (left) and after (right) the addition of $\mathrm{Na}^{14} \mathrm{CN}$ as revealed by ultraviolet scanning profile and bioautography. The peak and the antibacterial spot corresponding to saframycin $\mathrm{A}$ in ultraviolet absorbancy and bioautography respectively increased significantly with a concurrent decrease in the slow moving substances at $\mathrm{Rfs}$ around $\mathbf{0 . 2}$. The highest radioactivity also coincided with the peak of

Fig. 5. Potentiation of saframycin $\mathrm{A}$ in culture filtrate by $\mathrm{NaCN}$ as revealed in thin-layer chromatography.

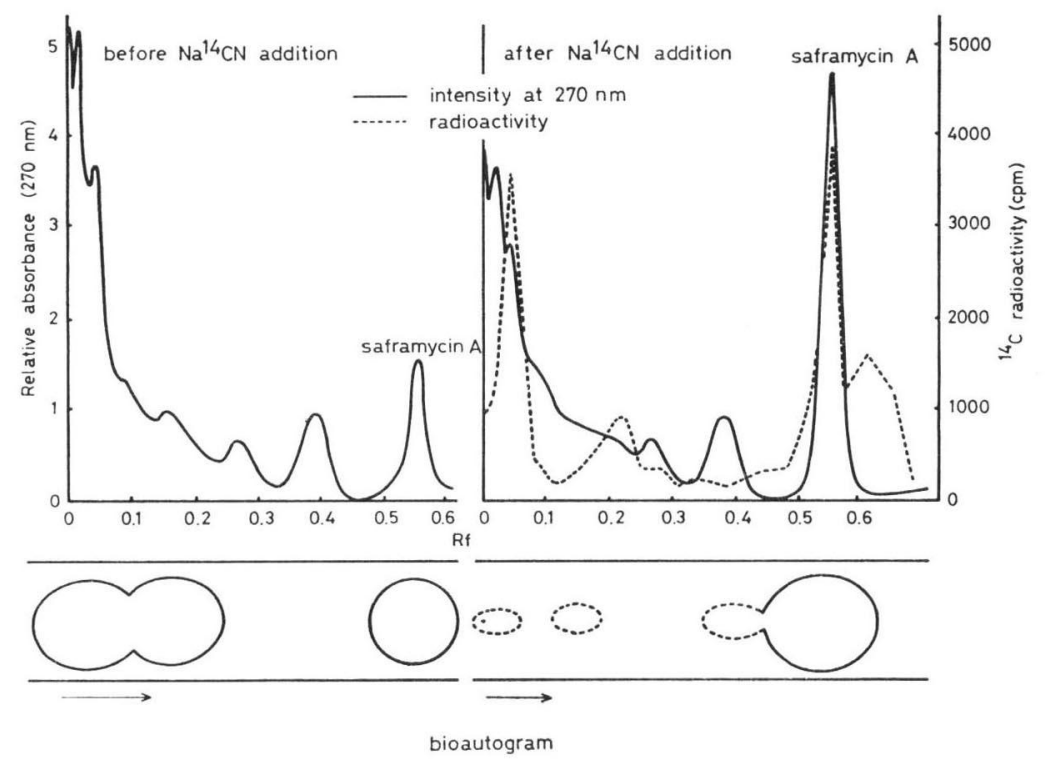


ultraviolet absorbancy. These experimental results strongly suggested that the radioactive nitrile group was actually incorporated into the molecule of saframycin A and that the incorporation was the result of cyanation of a certain precursor of the antibiotic.

\section{Prevention of Saframycin A Degradation in the Culture}

With the final aim to maintain a high level of saframycin A concentration during fermentation and the later extraction, we studied the stability of the antibiotic in a $\mathrm{pH}$ range between 1.0 and 8.0 in the presence and absence of resting cells of the producer strain. The results are presented in Table 3 and Fig. 6. In the absence of resting cells saframycin A was fairly stable at $\mathrm{pH}$ below 7.0 and a decrease in activity was only observed at $\mathrm{pH}$ 8.0. On the contrary, in the presence of $10 \%$ resting cells significant degradation occurred already at $\mathrm{pH}$-values over 4.0. As shown in Fig. 6, the degradation was accompanied by the appearance of slow moving, less active substances. The regulation of $\mathrm{pH}$ of the culture after appearance of the production peak of saframycin A, which was reasonably estimated by purple coloration of the mycelia, was then attempted and the results are shown in Fig. 7. In the control culture, saframycin A concentration tended to decrease rapidly after reaching the peak, while a prolonged maximum stationary phase appeared in the culture adjusted to a constant $\mathrm{pH}$ of 5.5 . A further protraction was attainable at $\mathrm{pH} 5.0$ which would allow ample time for termination of the fermentation and for the extraction of the antibiotic. The improvement of medium ingredients and cultural conditions coupled with the potentiation with $\mathrm{NaCN}$ as described above resulted in an about 1000 -fold increase in saframycin A production: The original concentration of $0.01 \mathrm{mcg} / \mathrm{ml}$ could be raised to a level of more than $10 \mathrm{mcg} / \mathrm{ml}$.

Table 3. Stability of saframycin $\mathrm{A}$ at various $\mathrm{pH}$ in MCILVAINE buffer with or without resting cells.

\begin{tabular}{c|c|c}
\hline \multirow{2}{*}{$\mathrm{pH}$} & \multicolumn{2}{|c}{ Potency $(\mathrm{mcg} / \mathrm{ml})$} \\
\cline { 2 - 3 } & Control & Resting cells \\
\hline 1.0 & 0.31 & 0.29 \\
2.2 & 0.28 & 0.28 \\
3.0 & 0.26 & 0.24 \\
4.0 & 0.27 & 0.23 \\
5.0 & 0.26 & 0.03 \\
6.0 & 0.28 & 0.01 \\
7.0 & 0.27 & 0.01 \\
8.0 & 0.20 & 0 \\
\hline
\end{tabular}

Fig. 6. Degradation of saframycin A with and without resting cells of S. lavendulae No. 314.

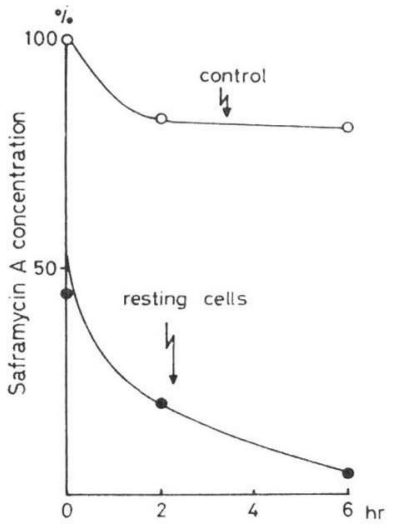
(solvent system: AcOEt: Benzene 2:1)
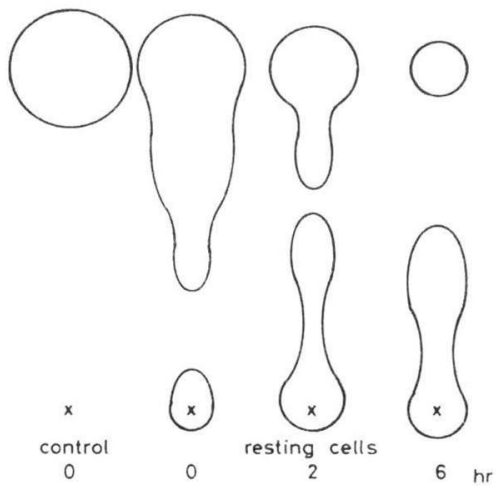
Fig. 7. Effect of $\mathrm{pH}$ regulation on saframycin A stability.
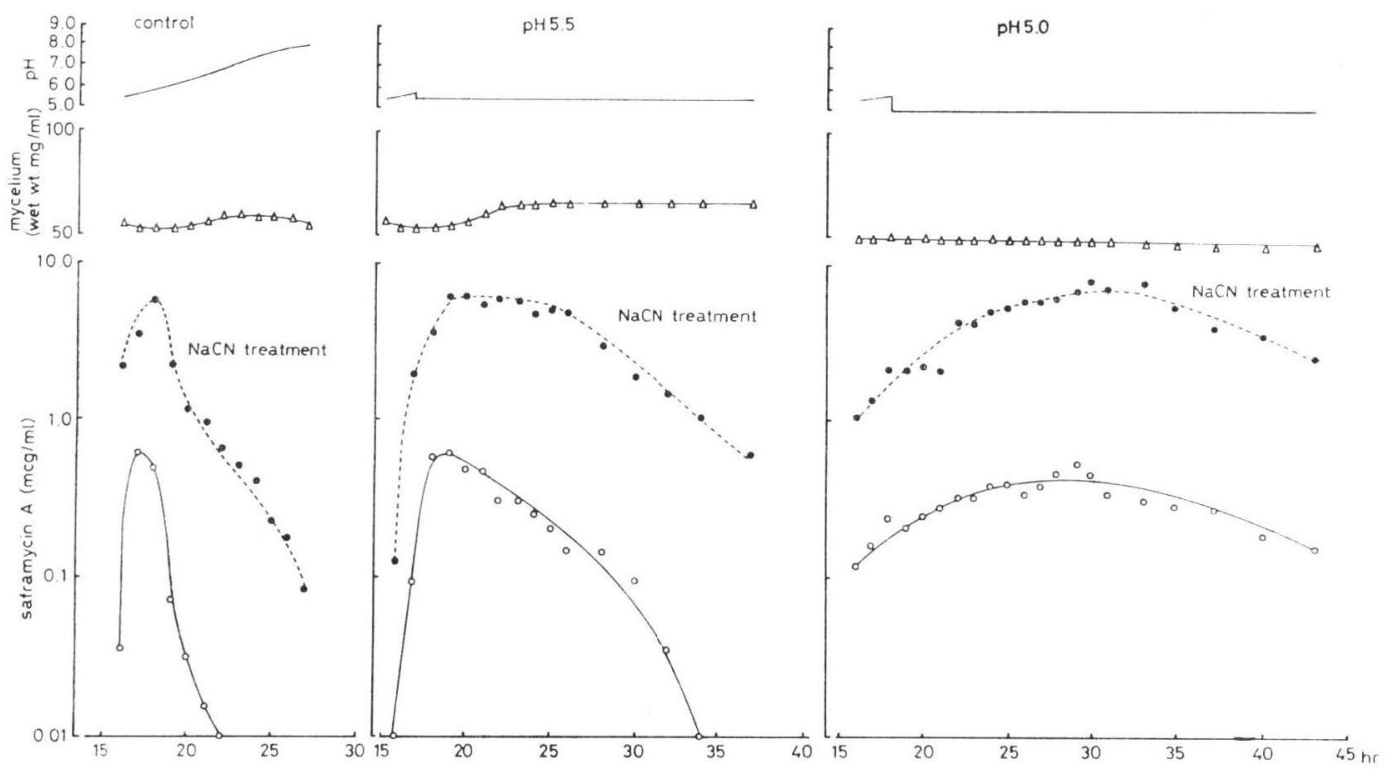

Isolation and Characterization of Saframycin $\mathrm{S}$

The precursor of saframycin A, and probably of all the saframycins, was subsequently isolated, characterized and designated as saframycin S. Saframycin S was isolated from the culture broth as follows: Eighty four liters of 20-hours culture filtrate was repeatedly extracted with chloroform totalling to 30 liters. The collected solvent layer was dried with anhydrous $\mathrm{Na}_{2} \mathrm{SO}_{4}$ and the solvent was removed in vacuo. The dark reddish brown residue was dissolved in $300 \mathrm{ml}$ of ethyl acetate. The ethyl acetate solution was washed with a small amount of water and the antibiotic was counter-extracted into $1 \mathrm{~N}$ $\mathrm{HCl}$. The aqueous layer was carefully adjusted to $\mathrm{pH} 8.0$ and extracted with dichloromethane. The solvent layer was washed with water and dried with anhydrous $\mathrm{Na}_{2} \mathrm{SO}_{4}$. On removal of the solvent $2.7 \mathrm{~g}$ of a dark red solid were obtained. The crude material containing saframycins was purified by silica gel column chromatography. The column was successively developed with the solvent mixtures benzene - ethyl acetate 10:1, 4:1, and 2:1. Saframycin $S$ was eluted in the fraction developed by the last solvent mixture. The compound was further purified by preparative thin-layer chromatography on a silica gel plate with ethyl acetate as a solvent; $34 \mathrm{mg}$ of the antibiotic were recovered from a yellow band of Rf 0.37. Saframycin $\mathrm{S}$ showed $\mathrm{Rf}$ values of $0.45,0.25$ and 0.16 with the solvent mixtures benzene - acetone (1:1), benzene - ethyl acetate (1:3) and chloroform - ethyl acetate (1:1), respectively. Saframycin $\mathrm{S}$ was also prepared by mild acid hydrolysis and subsequent decyanization of saframycin A. Five hundred sixty two mg of saframycin A were treated with $200 \mathrm{ml}$ of $0.1 \mathrm{~N} \mathrm{H}_{2} \mathrm{SO}_{4}$ in a flask, fitted with a Liebig condenser, at $120^{\circ} \mathrm{C}$ for 40 minutes. Simultaneously, volatilized HCN gas was collected into $2 \% \mathrm{NaOH}$ solution. The reaction mixture was then carefully adjusted to $\mathrm{pH}$ 7.0 and extracted twice with equal amounts of ethyl acetate. The solvent layer was dried and the purification of the antibiotic was performed as described above; $228 \mathrm{mg}$ of the antibiotic were obtained in a yield of $40.5 \%$ and its identity with saframycin $\mathrm{S}$ was confirmed by thin-layer chromatography and other physico-chemical properties. 
Saframycin $\mathrm{S}$ was obtained as a dark yellow powder melting at $107 \sim 115^{\circ} \mathrm{C}$ (dec.), and its optical rotation showed $[\alpha]_{D}^{25}+32.5^{\circ}(c 0.5$, $\mathrm{MeOH})$. Elemental analysis gave the following values: C $61.45, \mathrm{H} 6.18, \mathrm{~N} 7.48$. The calculated values for $\mathrm{C}_{28} \mathrm{H}_{31} \mathrm{~N}_{3} \mathrm{O}_{9}$ are $\mathrm{C} 60.75, \mathrm{H} 5.65, \mathrm{~N}$ 7.59. The ultraviolet absorption spectrum of saframycin $\mathbf{S}$ in methanol (Fig. 8) had one absorption maximum. UV $\lambda_{\max }^{\mathrm{MeOH}} \mathrm{nm}(\log \varepsilon): 268$ (4.21), $\lambda_{\min }^{\mathrm{MeOHI}} \mathrm{nm}(\log \varepsilon): 234$ (3.92). The infrared absorption spectrum of saframycin $\mathrm{S}$ is shown in Fig. 9; IR $\nu_{\max }^{\mathrm{CHCl}_{3}} \mathrm{~cm}^{-1}$ : 3400, 1720, 1680, 1650.

The proton magnetic resonance spectrum of saframycin $\mathrm{S}$ is shown in Fig. 10 ; PMR $\left(\delta, \mathrm{CDCl}_{3}, 100\right.$ $\mathrm{Mz}): 1.94\left(3 \mathrm{H}, \mathrm{s},-{ }_{\mathrm{C}}^{\mathrm{C}}=\stackrel{\mathrm{C}}{\mathrm{C}}-\mathrm{CH}_{3}\right), 2.06\left(3 \mathrm{H}, \mathrm{s},-\stackrel{\mathrm{C}}{\mathrm{C}}=\mathrm{C}-\mathrm{CH}_{3}\right), 2.30\left(3 \mathrm{H}, \mathrm{s},-\mathrm{CO}-\mathrm{CH}_{3}\right), 2.52\left(3 \mathrm{H}, \mathrm{s},-\mathrm{N}-\mathrm{CH}_{3}\right)$, $4.06\left(3 \mathrm{H}, \mathrm{s},-\mathrm{C}=\mathrm{C}-\mathrm{OCH}_{3}\right)$. Saframycin $\mathrm{S}$ was soluble in lower alcohols, chloroform, ethyl acetate, acetone and ether, and insoluble in water. The antibiotic gave a positive reaction with DRAGENDORFF reagent.

Fig. 9. IR spectra of saframycin $\mathrm{S}$ and the acid hydrolysis product of saframycin $\mathrm{A}$

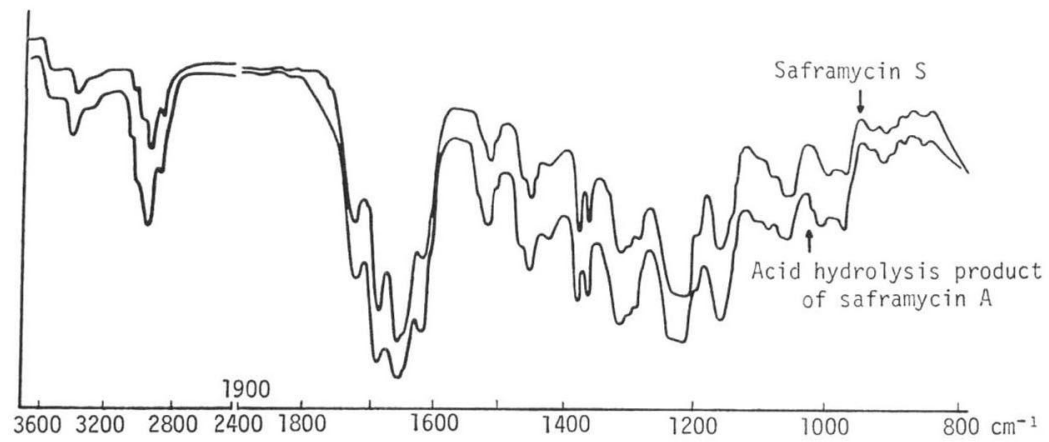

Table 4. CMR spectra of saframycins $\mathrm{S}$ and $\mathrm{A}$.

\begin{tabular}{l|l|l|l|l|l}
\hline $\begin{array}{c}\text { Carbon } \\
\text { No. }\end{array}$ & \multicolumn{1}{|c|}{ Saframycin S } & \multicolumn{1}{|c|}{ Saframycin A } & \multicolumn{1}{|c|}{$\begin{array}{c}\text { Carbon } \\
\text { No. }\end{array}$} & \multicolumn{1}{|c}{ Saframycin S } & Saframycin A \\
\hline$-\mathrm{CO}-\mathrm{CH}_{3}$ & $196.7(\mathrm{~s})$ & $196.7(\mathrm{~s})$ & $-\mathrm{OCH}_{3}(7,17)$ & $61.1(\mathrm{q}) \times 2$ & $61.1(\mathrm{q}) 61.0(\mathrm{q})$ \\
5,15 & $188.6(\mathrm{~s}) 185.6(\mathrm{~s})$ & $186.5(\mathrm{~s}) 185.2(\mathrm{~s})$ & $1,11,3,13$ & $55.0(\mathrm{~d}) 54.1(\mathrm{~d})$ & $56.3(\mathrm{~d}) 54.6(\mathrm{~d})$ \\
8,18 & $182.9(\mathrm{~s}) 180.9(\mathrm{~s})$ & $183.4(\mathrm{~s}) 180.8(\mathrm{~s})$ & & $52.9(\mathrm{~d}) 49.7(\mathrm{~d})$ & $54.3(\mathrm{~d}) 54.0(\mathrm{~d})$ \\
$-\mathrm{NH}-\mathrm{CO}-$ & $160.0(\mathrm{~s})$ & $160.2(\mathrm{~s})$ & $-\mathrm{NCH}_{3}$ & $42.5(\mathrm{q})$ & $41.6(\mathrm{q})$ \\
7,17 & $156.0(\mathrm{~s}) \times 2$ & $155.6(\mathrm{~s}) 155.9(\mathrm{~s})$ & 22 & $41.1(\mathrm{t})$ & $40.7(\mathrm{t})$ \\
10,20 & $141.1(\mathrm{~s}) 133.9(\mathrm{~s})$ & $141.6(\mathrm{~s}) 141.2(\mathrm{~s})$ & 4 & $25.2(\mathrm{t})$ & $25.1(\mathrm{t})$ \\
9,19 & $137.3(\mathrm{~s}) 135.1(\mathrm{~s})$ & $135.6(\mathrm{~s}) \times 2$ & $\mathrm{CO}-\mathrm{CH}_{3}$ & $24.3(\mathrm{q})$ & $24.3(\mathrm{q})$ \\
6,16 & $129.5(\mathrm{~s}) 127.8(\mathrm{~s})$ & $129.2(\mathrm{~s}) 128.3(\mathrm{~s})$ & 14 & $21.0(\mathrm{t})$ & $21.6(\mathrm{t})$ \\
$-\mathrm{CN}$ & & $116.7(\mathrm{~s})$ & $-\mathrm{CH}_{3}(6,16)$ & $8.8(\mathrm{q}) \times 2$ & $8.7(\mathrm{q}) \times 2$ \\
21 & $81.6(\mathrm{~d})$ & $58.3(\mathrm{~d})$ & & & \\
\hline
\end{tabular}

(s): singlet, (d): doublet, (t): triplet, $(\mathrm{q})$ : quartet.

value in ppm from TMS 
Fig. 10. PMR spectrum of saframycin S.

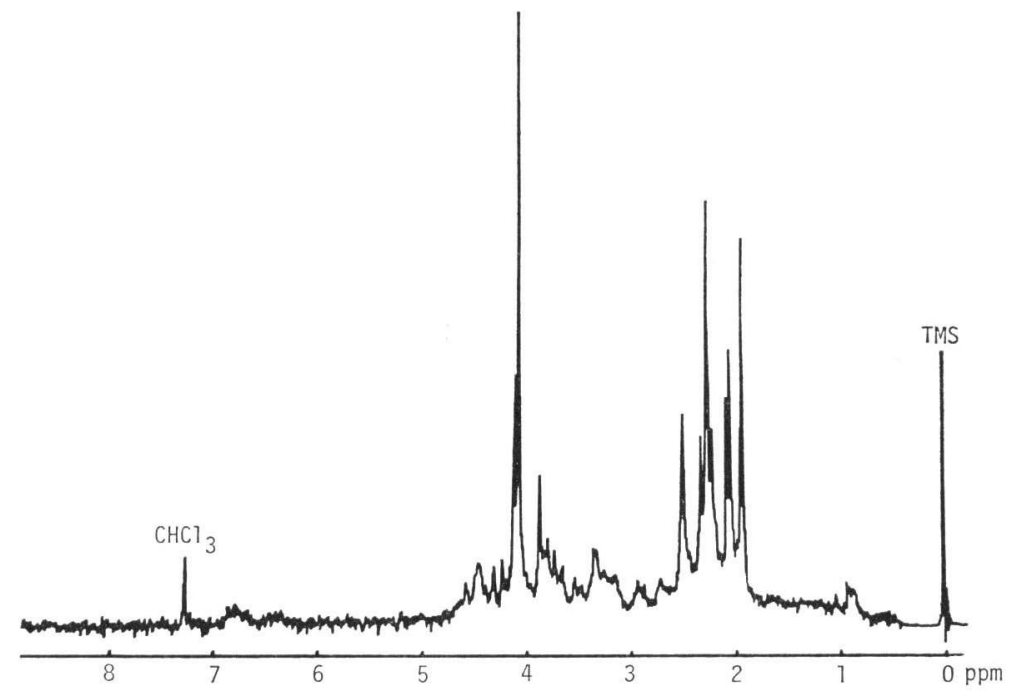

The UV spectrum of saframycin $\mathbf{S}$ is identical with that of saframycin $A$. In the PMR spectrum of saframycin S are shown six methyl groups as in the spectrum of saframycin A. Thus, the basic skeleton of saframycin $\mathrm{S}$ is assumed to be identical with that of saframycin $\mathrm{A}$.

On the other hand, an absorption ascribed to hydroxy group $\left(\nu_{\mathrm{OH}}^{\mathrm{CH} \mathrm{Cl}_{3}} 3400 \mathrm{~cm}^{-1}\right)$ in the IR spectrum of saframycin S, was not observed in the spectrum of saframycin A. The carbon magnetic resonance spectra of saframycins A and S are shown in Table 4. The signals at $\delta 116.7$ (s) and $\delta 58.3$ (d) of saframycin A disappeared with saframycin S, while a new signal appeared at $\delta 81.6$ in doublet. Although the signal at $\delta 81.6$ (d) was in a field too low for the carbon substituted hydroxy group, it was logically assigned for the carbon in $\alpha$-carbinolamine form. Consequently, the structure of saframycin $\mathrm{S}$ is reasonably explained in that the C-21 cyano group of saframycin $\mathrm{A}$ is substituted with a hydroxy group.

Furthermore, the reaction product of saframycin $\mathrm{S}$ and $\mathrm{NaCN}$ in neutral or acidic solution was identified as saframycin A by TLC, using several solvent systems, and by the mass, CMR, and IR spectra. These experimental results are also in support of the C-21 hydroxy substituted $\alpha$-carbinolamine structure of saframycin $\mathbf{S}$. The structure

Fig. 11. Structure of saframycin $\mathbf{S}$. of saframycin S, thus determined by several spectroscopic data and chemical reactions, is shown in Fig. 11. As shown in this figure, saframycin $\mathrm{S}$ is assumed to be present in two interconvertible forms in the culture filtrate, i.e. iminium salt or $\alpha$-carbinolamine.
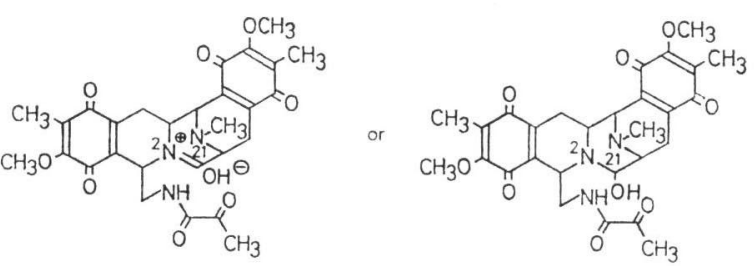

\section{Discussion}

Studies on the increased production of saframycin A not only made it possible to develop the antibiotic as an antitumor chemotherapeutic substance but also revealed a novel biological modification of the precursor of saframycin group antibiotics, which led to the discovery of saframycin S. A 
unique feature of the production of saframycin A, the potency of which is the most distinguished among saframycins, by $S$. lavendulae No. 314 is thus the co-production of cyanide with the saframycin precursor. But, according to the present experimental results, few streptomyces seem to produce cyanide in their cultures. The results presented above also seem to supply some clue to the possible isolation and development of biologically active trace metabolites in cultures of streptomyces strains.

During the studies on the mode of action of saframycin A, it was revealed that the antibiotic has to be reduced prior to its interaction with DNA with simultaneous release of the nitrile group from its molecule ${ }^{13)}$. Saframycin $\mathrm{S}$ in an $\alpha$-carbinolamine form might be an active form to interact with DNA molecules. It is interesting, therefore, to study the reaction of saframycin $\mathbf{S}$ with reference to the mode of action of saframycin A. As will be reported elsewhere there are also ample evidences which indicate higher biological activities of saframycin $\mathrm{S}$ than those of saframycin $\mathrm{A}$.

On the other hand, saframycin $\mathrm{S}$, with a site at $\mathrm{C}-21$ position more reactive than that of other saframycins, seems to be a profitable compound for the preparation of chemically modified saframycins which might meet diverse demands in cancer chemotherapy.

\section{References}

1) Arai, T.; K. Takahashi \& A. Kubo: New antibiotics, saframycins A, B, C, D and E. J. Antibiotics 30 : $1015 \sim 1018,1977$

2) Arai, T.; K. Takahashi, A. Kubo, S. Nakahara, S. Sato, K. Aiba \& C. Tamura: The structure of novel antibiotics, saframycin B and C. Tetrahed. Lett. 1979: 2355 2358, 1979

3) Arai, T.; K. Takahashi, S. Nakahara \& A. Kubo: The structure of a novel antitumor antibiotic, saframycin A. Experientia, in press

4) Arai, T.; Y. Mikami, K. Okamoto, H. Tokita \& K. Terao: The nude mouse in experimental cancer chemotherapy. in "Advances in cancer chemotherapy" pp. 235 251. Japan Scientific Society Press, Tokyo/University Park Press, Baltimore, 1978

5) ARai, T.; K. TAKahashi, K. Ishiguro \& Y. Mikami: Observation concerning some chemotherapeutic properties of new antitumor antibiotics, saframycin A and C. Gann 6: in press

6) Arai, T.; K. YaZAWA, K. Ishiguro \& K. TAKahashi: Preparation of saframycin $\mathbf{S}$ (decyanosaframycin A) and mechanism of the binding saframycin A to DNA. in "Current chemotherapy and infectious disease (Proceedings of the 11th ICC and the 19th ICAAC)" Vol. II, pp. 1556 1557, The American Society for Microbiology, Washington, DC, 1980

7) ARAI, T.: Screening of anticancer drugs (Review). Ferment. \& Indust. (Tokyo) 37: 644 655, 1979 (in Japanese)

8) ARAI, T.; K. YaZAWA, Y. Mikami, A. Kubo \& K. TAKAhashI: Isolation and characterization of satellite antibiotics, mimosamycin and chlorocarcins from Streptomyces lavendulae, streptothricin source. J. Antibiotics 29: 398 407, 1976

9) Mikami, Y.; K. Yokoyama, A. Ômi \& T. AraI: Identification of producer and biological activities of new antibiotics, mimosamycin and chlorocarcins. J. Antibiotics 29: 408 414, 1976

10) SHIIO, I: Microbial production of amino acids and metabolic regulation. Seikagaku (Tokyo) 50: 1 16, 1978 (in Japanese)

11) Michaels, R. \& W. A. Corpe: Cyanide formation by Chromobacterium violaceum. J. Bacteriol. 89: $106 \sim 112,1965$

12) Castric, P. A.: Glycine metabolism by Pseudomonas aeruginosa: Hydrogen cyanide biosynthesis. J. Bacteriol. 130: 826 831, 1977

13) Ishiguro, K.; S. Sakiyama, K. TAKahashi \& T. Arai: Mode of action of saframycin A, a novel heterocyclic quinone antibiotic. Inhibition of RNA synthesis in vitro and in vivo. Biochemistry 17: 2545 2550,1978 